\title{
Bacterial Survey of Diabetic Ulcers in Diabetic Patients in Hospitals at Aba, Nigeria
}

\author{
Akunneh Wariso $\mathrm{C}^{1}$ and Aduema $\mathrm{W}^{2 *}$ \\ ${ }^{1}$ Department of Human Physiology, Abia State University, Uturu, Nigeria \\ ${ }^{2}$ Department of Human Physiology, PAMO, University of Medical Sciences, Port Harcourt Rivers State, Nigeria \\ *Corresponding author: Aduema Wadioni, Department of Human Physiology, PAMO University of Medical Sciences, Port \\ Harcourt, Rivers State, Nigeria
}

\section{ARTICLE INFO}

Received: 幽 May 31, 2019

Published: 慧 June 20, 2019

Citation: Akunneh Wariso C and Aduema W. Bacterial Survey of Diabetic Ulcers in Diabetic Patients in Hospitals at Aba, Nigeria. Biomed J Sci \& Tech Res 19(1)2019. BJSTR. MS.ID.003236.

\begin{abstract}
Diabetic ulcers are usually seen as infected ulcers and run a chronic course. Selected documented records of diabetic patients with diabetic ulcers were taken from the laboratory sections of different hospitals and clinics in Aba. From these records, a total of 110 diabetic ulcer cases were used in this study irrespective of their sexes and ages. Trauma related ulcers were ruled out. Microscopy and culture of specimen or wound swabs from these ulcers after 48 hours at 360C incubation showed that the most common bacteria in these ulcers is Escherichia Coli (E.coli) followed by staphylococcus species which is $22 \%$. These bacteria species were seen in most of these ulcers. This study showed that most diabetic ulcers are mostly or commonly infected by Escherichia species and staphylococcus species.
\end{abstract}

Keywords: Diabetic Ulcer; Patient; E.Coli; Bacteria

\section{Introduction}

Diabetes mellitus is one of the commonest diseases in tropical areas.Diabetesmellitusmaybedescribedasasyndromecharacterized by hyperglycemia and disturbance of carbohydrate, fat and protein metabolism resulting from defects in insulin secretion, insulin action or both [1]. Aside complications like diabetic nephropathy, neuropathy and retinopathy, diabetic ulcers are seen as the most troubling problem in the hospitals and clinics [2]. Most times, it involves the attention of both surgeon and internal physicians. It has been reported that diabetic complications are associated with overproduction of Reactive Oxygen Species (ROS) [3]. This complication is considered the leading cause of death among these patients. Oxidation plays a major role in diabetes [4]. The increase in free radical release accompanied by decrease in antioxidants is a major cause of diabetes [5]. In diabetes mellitus, there are usually alterations in the endogenous free radical scavenging defenses which leads to ineffective scavenging of reactive oxygen species resulting to oxidative damage [6]. Experimental diabetes induced by streptozotocin, selectively destroys the $\beta$-cells of pancreas by generating excess reactive oxygen species and produces kidney lesions that are similar to human diabetic nephropathy [7]. Studies have shown that individuals with diabetes have a higher incidence of kidney function abnormalities, as well as formation of free radical due to glucose oxidation, non-enzymatic glycosylation of proteins and subsequent oxidative degradation of glycated proteins, leading to a decline in antioxidant defense mechanism and damage of cellular organelles and enzymes and development of insulin resistance which ultimately, culminate in renal complications $[8,9]$. Thus, an early control of DM is recommended as one of main strategy to prevent these complications and increase the life span of these patients. Knowledge of the common pathogens associated with diabetic ulcers may hasten quick recovery of the patients as definitive therapy will be applied after confirmatory results of wound swab culture.

\section{Materials and Methods}

A retrospective study of confirmed 110 diabetic patients with diabetic ulcers managed in different hospitals and clinics at Aba over 9 months were taken from the laboratory sections of the hospitals and clinics irrespective of their sexes and ages. Trauma related ulcers were ruled out. Specimens or wound swabs from different ulcers were taken before commencement of treatment under sterile conditions for microscopy, culture and sensitivity (MSC) at 300cincubation for 48 hours. The results of these ulcer 
and wound swabs were shown below. It should be noted that some of these patients had been on treatment either from patent medicine dealers or other clinics without records.

\section{Ethical Consideration}

Ethical approval was obtained from the State ministry of Health,
Aba State; Nigeria. Consent from patient's from whom data's were obtained".

\section{Result}

Bacterial survey of diabetic ulcers in diabetic patients (Figure 1) and (Table1).

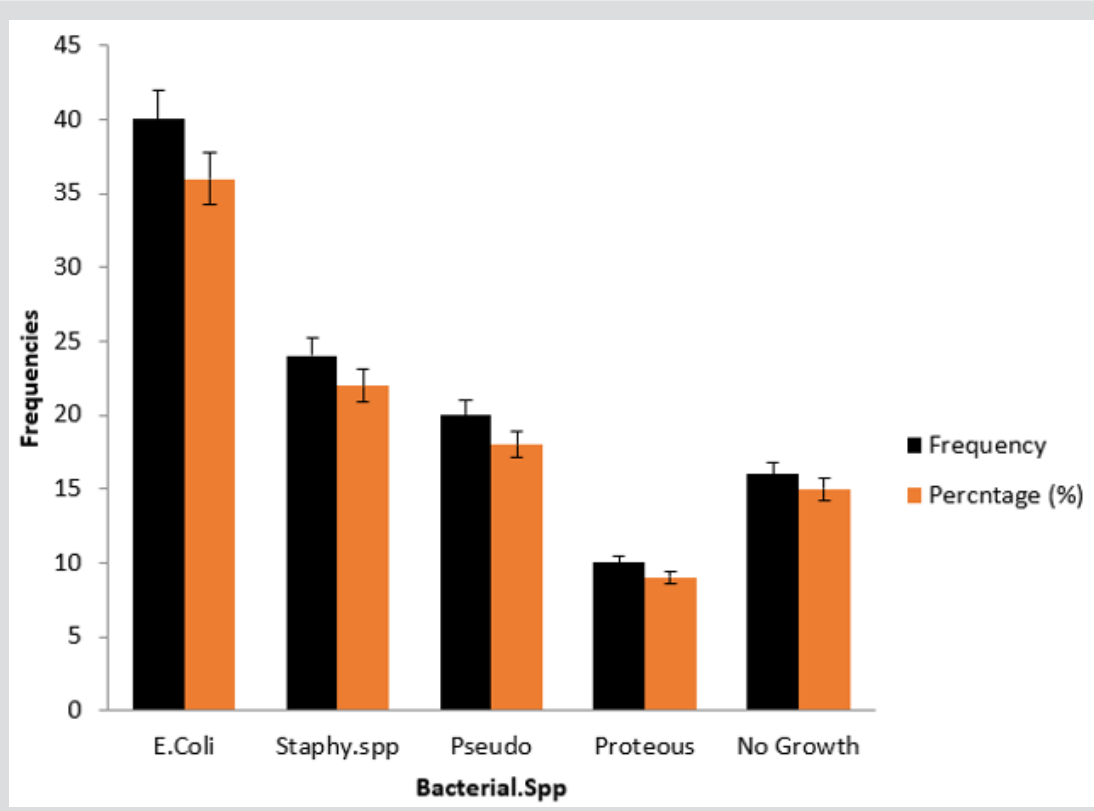

Figure 1: Bacterial survey of diabetic ulcers in diabetic patients.

Table 1.

\begin{tabular}{|c|c|c|}
\hline Bacterial spp. & Frequency & Percentage (\%) \\
\hline Escherichia Coli (E coli) & 40 & 36.0 \\
\hline Staphylococcus spp. & 24 & 22.0 \\
\hline Pseudomonas spp. & 20 & 18.0 \\
\hline Proteus spp. & 10 & 9.0 \\
\hline No significant bacterial growth & 16 & 15.0 \\
\hline Total & 110 & 100 \\
\hline
\end{tabular}

\section{Discussion}

Aside complications like diabetic nephropathy, diabetic ulcers are seen as the most troubling problem in the hospital and clinics [2].Thus early control is recommended as one of the main strategy to prevent these complications. Diabetic ulcer if not checked leads to the destruction of body tissues and impair patient's quality of life. Most diabetic ulcers can be prevented with good care and screening of people for risk factors [10]. It has also been implicated as one of the causes of Charot arthropathy $[11,12]$, which involves progressive damage to the bones, joints and tissues of the body $[12,13]$.

Therefore, the aim of this study was to carry out a bacterial survey of diabetic ulcers among diabetic patient in Aba, hospital in Abia State, Nigeria. Documented medical records of 110 confirmed diabetic patients admitted and managed in different hospitals and clinics at Aba were taken. Specimens or wound swabs were taken before commencement of treatment, though some patients would have being in several antibiotics without records. Our findings showed that Out of 110 diabetic patients with diabetic ulcers, specimens or wound swabs from these patients showed that $36.0 \%$ of cases were infected with Escherichia coli, $22.0 \%$ cases with Staphylococcus spp. This result also showed that $18.0 \%$ and $9.0 \%$ of cases were infected with pseudomonas spp and proteus spp respectively. Cultures of specimens or wound swabs of $15.0 \%$ of cases showed no significant growth. This indicated that these patients had being on several antibiotics in other places with no documentation or records.

\section{Conclusion}

In conclusion, our bacterial survey of diabetic ulcers in diabetic patients revealed that the most predominant bacterial in diabetic ulcers in our center is Escherichia coli (E. coli) followed by Staphylococcus spp. Therefore, the knowledge of this bacterial survey will be useful in management of diabetic ulcers. 


\section{References}

1. Falase AO, Akinkugbe $O O$ (2006) A Compendium of Clinical Medicaine.

2. Giorgino F, Lavida L, Cavallo PP, Solnica B, Fuller J, et al. (2004) Factors associated with progression to macroalbuminuria in microalbuminuric type 1 diabetic patient: The EURODIAB prospective complications study. Diabetologia 47(6): 1020-1028.

3. Palanduz S, Ademoglu E, Gokkusu C, Tamer S (2001) Plasma antioxidants and type 2 diabetes mellitus. Pharmacology 109(5-6): 309-318.

4. Lieber CS (1997) Ethanol metabolism, cirrhosis and alcoholism. Clin Chim Acta 257(1): 59-84.

5. Mohamed AK, Bierhaus A, Schiekofer S, Tritschlet H, Ziegler R, et al. (1999) The role of oxidative stress and NF (B) activation in late diabetic complications. Biofactors 10(2-3): 157-167.

6. Oberley LW (1988) Free radicals and diabetes. Free Radic Biol Med 5(2): 113-124.

7. Boukhris M, M Bouaziz, I Feki, H Jemai, A Feki EL, et al. (2012) Hypoglycemic and antioxidant effects of leaf essential oil of Pelargonium

\section{ISSN: 2574-1241}

DOI: 10.26717/BJSTR.2019.19.003236

Aduema W. Biomed J Sci \& Tech Res

(C) This work is licensed under Creative

Submission Link: https://biomedres.us/submit-manuscript.php graveolens L'Hér. in alloxan induced diabetic rats. Lipids Health Dis 11: 81.

8. Kangralkar VA, Shivraj DP, Bandivadekar RM (2010) Oxidative stress and diabetes: a review. International Journal of Pharmaceutics 1(1): 38-45.

9. Dabla PK (2010) Renal function in diabetic nephropathy. World Journal of Diabetes 1(2): 48-56.

10. Zhang P, Lu J, Jing Y, Tang S, Zhu D, et al. (2017) Global epidemiology of diabetic foot ulceration: a systemic review and meta-analysis. Ann Med 49(2): 106-116.

11. (2017) American Diabetes Association. Standard of Medical Care in diabetes. Abridged for primary care providers. Clinical Diabetes 35: 5-26.

12. Rogers LC, Frykberg RG, Sanders IJ (2016) The diabetic Charcot foot: recognition, evaluation and management. In: Amstrong DG, Lavery LA (Eds.), Clinical care of the diabetic foot $3^{\text {rd }}$ (edn.). 99.

13. Pop Busiu R, Boulton AJM, Feldman EL, Vera Bril, Roy Freeman, et al. (2017) Diabetic neuropathy: A position statement by the American Diabetic Association. Diabetes care 40(1): 136-154.

$\begin{array}{ll}\text { BIOMEDICAL } & \text { Assets of Publishing with us } \\ \text { RESEARCHES } & \text { - Global archiving of articles } \\ & \text { - Immediate, unrestricted online access } \\ & \text { - Rigorous Peer Review Process } \\ \end{array}$

